\title{
Research on the Status Quo and Guarantee Mechanism of Labor Rights and Interests of College Interns
}

\author{
Peiyun Tang, Xia Gao \\ Southwest Minzu University, Chengdu, China \\ Email: 1073006749@qq.com
}

How to cite this paper: Tang, P. Y., \& Gao, X. (2021). Research on the Status Quo and Guarantee Mechanism of Labor Rights and Interests of College Interns. Open Journal of Social Sciences, 9, 181-188. https://doi.org/10.4236/jss.2021.97012

Received: June 21, 2021

Accepted: July 16, 2021

Published: July 19, 2021

Copyright $\odot 2021$ by author(s) and Scientific Research Publishing Inc. This work is licensed under the Creative Commons Attribution International License (CC BY 4.0).

http://creativecommons.org/licenses/by/4.0/

\section{(c) (i) Open Access}

\begin{abstract}
With the continuous progress of economic and social development, more and more students have had the opportunity to receive higher education, which has strengthened the high-quality talent team, but with it, a large number of college graduates are facing an increasingly fierce employment situation. Therefore, most college students will start internships before graduation, in order to better adapt to the society and enhance their professional capabilities and core competitiveness. However, college students with relatively junior qualifications do not know how to protect their labor rights during the internship process, and they are often at a loss when their labor rights are damaged. This paper investigates the status quo of labor rights and interests protection of some college interns through questionnaires, analyzes the root problems in their status quo, and proposes reasonable and feasible countermeasures to effectively protect the labor rights of interns and further alleviate the social contradictions caused by internship issues.
\end{abstract}

\section{Keywords}

Interns, Labor Rights, Status Quo, Guarantee Mechanism

\section{Introduction}

Since the expansion of enrollment in colleges and universities in 1999, while helping students realize their college dreams, the number of college graduates has also increased year by year. According to data released by the Ministry of Education, the number of college graduates in 2020 has reached 8.74 million, and the number of college graduates in 2021 is expected to reach 9.09 million, an increase of 350,000 compared with last year (Feng, 2015). For the current em- 
ployment situation, in my country, the biggest employment pressure for college graduates will always be next year. Regardless of the intensity of employment competition, most students will accumulate work experience, improve practical ability, and enhance their employment competitiveness through internships. However, there is currently no current employment competition in my country. Laws and regulations make clear provisions on the labor rights and interests of interns in colleges and universities. After the labor rights and interests of interns are damaged, it is difficult for them to obtain timely and effective relief due to their unclear legal status. In the international society, because developed countries have clear certainty about whether the identities of school students belong to laborers, there is a relatively complete social security system and commercial insurance system for university interns: whether it is universities, governments or social organizations, there are all about university students. The clear regulations and management institutions for internships are therefore worth learning from our country. Foreign research on the protection of the rights and interests of college students during the internship period is biased towards fairness and orientation. Compared with universities and internship units, interns are in a weak position ( $\mathrm{Du}, 2015)$. This article takes some college students and graduate students in Chengdu as an example, investigates the status quo of labor rights protection of college interns through questionnaires, and proposes corresponding solutions to escort college students' practical internship activities, build more harmonious labor relations and promote the continuous and positive development of individual college students and the entire society.

\section{Analysis of the Current Status of Labor Rights Protection for Interns}

Through questionnaire surveys, this paper reveals a series of issues concerning the protection of labor rights and interests of interns in colleges and universities, such as the working conditions and remuneration levels. The survey was mainly aimed at college students in Chengdu, and a total of 98 questionnaires were collected, including 98 valid questionnaires. There are 19 questions in this questionnaire. The subjects of the survey are college students and postgraduates in general institutions of higher learning. The following is the status quo of the labor rights and interests of interns:

\subsection{Interns Are in a Disadvantaged Position}

Enterprises provide internship positions for college students, select suitable intern candidates according to certain standards, have the right to decide whether or not interns will stay, and hold the initiative. Facing the intern market where there are "more monks and porridge", internship units often have a lot of choice. The large number of college interns with lack of experience and abilities will inevitably appear passive and lack of confidence in front of the internship receiving unit. The survey shows that $32.8 \%$ of students still said that they have not 
signed an internship agreement with the internship unit. In addition, they lack special laws and regulations to effectively protect their labor rights during the internship. Some are just agreements between two or three parties, but as individual natural persons, they are objectively in a disadvantaged position relative to legal persons. In addition, they are also subject to school management and the rules and regulations of the internship unit, the resources they control are extremely limited, and even their right to speak is weak.

\subsection{Poor Internship Quality and Limited Treatment}

According to the survey, in order to complete teaching tasks, some schools will organize students to internship units for short-term internships, but most internship units are perfunctory to college students' internships and have not invested sufficient time and energy. They arrange for students to do some daily chores such as serving tea and water, cleaning, moving things, typing and copying, or just ignore them. The practical ability of students has not been actually improved, and the dislocation between the content of the internship and the expectations of the internship has led to poor internship quality. The survey data shows that only $30 \%$ of the students have received systematic training, $47.3 \%$ of the students have received scattered training, and even $22.7 \%$ of the students have not received the training of the internship unit directly to work, and the effect of the internship is also uneven.

During the internship period, the internship unit should pay the internship remuneration after obtaining the results of the intern's labor. The lack of relevant internship remuneration standards has led companies to reduce the remuneration paid as much as possible. Due to the serious imbalance of supply and demand in the internship market, internship units are often in the buyer's market, and the actual benefits of interns are limited. In order to pursue immediate benefits, some internship units squeeze interns at will, increase the workload at will and require interns to leave work after they are completed, try to deduct the labor remuneration of interns, dismiss interns at will, etc., and use interns as cheap labor. Some units do not give any subsidies to interns and treat interns as free labor; some internship units even require college students to pay for internships so that they can spend money to get internship opportunities. Some internship units also force interns to extend their working hours by increasing the workload. $24.6 \%$ of students work more than 8 hours a day, and $58.7 \%$ of students said that they did not get the corresponding overtime wages for overtime work.

\subsection{The Labor Rights of Interns Are Not Guaranteed}

The status of interns is still students, and they do not belong to the scope of workers stipulated in the "Labor Law". The intern unit cannot pay for them social insurance. This prevents interns from obtaining work-related injury insurance and other social insurance systems. Interns are more likely to have acci- 
dents outside the school than on campus. However, due to the limitations of the student insurance paid by the school for on-campus students, accidents that occur during the off-campus internship are not covered by the student insurance. The survey showed that only $38.2 \%$ of the students said that the internship unit purchased personal accident insurance for them. If a major accident occurs, the students will not have any protection, and they will face huge medical expenses. In addition, in terms of work environment safety, the survey result shows that $15.5 \%$ of the interviewed students believe that the work environment is unsafe. It can be seen that the safety guarantee of interns also needs to be solved urgently, and we should pay enough attention to it.

\subsection{Ways and Effects of Rights Protection Are Not Good}

When the labor safety rights of interns are violated, only through effective remedies to solve the problem in time and make up for the loss to the greatest extent, can the labor rights of interns be truly protected. In the way of protecting rights, it was found that when the rights and interests of interns were violated, $60 \%$ of interns chose to first negotiate with the intern unit on how to solve the problem. $15.5 \%$ of interns reported to the school and asked the school to participate. $10.9 \%$ of interns would choose litigation procedures, and $10.9 \%$ of interns chose to seek help from relevant government departments. $2.7 \%$ of interns would choose to swallow their breath and consider themselves unlucky.

The labor rights and interests of interns are not clearly stipulated in the current laws and regulations, which also leads to the infringement of labor rights and interests of interns, and there is no way to defend their rights. The labor administrative department cannot rely on ruling such cases. If you take the civil litigation approach, the interns will consume more energy and financial resources, and the current law is also difficult to fully protect the legitimate rights and interests of interns. According to the survey results, $88.2 \%$ of interns took the approach of defending their rights. Among them, $61.9 \%$ felt general about the effect of their rights protection, while those who felt very poor and poor accounted for $4.1 \%$ and $10.9 \%$, respectively. The road to rights protection is still difficult and difficult.

\section{Root Analysis of the Lack of Labor Rights Protection for Interns}

\subsection{Imbalance of Rights of Interns}

Article 42 of the Constitution stipulates: "Citizens of the People's Republic of China have the rights and obligations to work. The state uses various channels to create employment conditions, strengthen labor protection, and increase labor remuneration and welfare benefits based on the development of production."This shows that interns have the same labor rights as ordinary workers. The right to work, also known as the right to labor security, refers to the right of citizens who have the ability to work to have access to labor opportunities and 
appropriate working conditions, and to obtain labor remuneration in accordance with the quantity and quality of their labor. The labor provided by interns is the same as that of regular employees. Interns should enjoy the same rights as regular employees, such as the right to rest and vacation, the right to labor remuneration, and the right to occupational safety. Due to the particularity of the identity of college interns, internships are not labor in the meaning of labor law, but a relatively flexible short-term internship relationship. Therefore, interns fail to enjoy their due rights.

\subsection{Absence of Labor Contract}

At present, China does not expressly stipulate that internship units must sign labor contracts with interns, and even some internship units do not sign any internship agreements with interns to clarify the rights and obligations of both parties. Article 2 of my country's "Labor Law" stipulates: “This law applies to enterprises, individual economic organizations within the territory of the People's Republic of China, and workers who have formed labor relations with them." From the perspective of the law, workers must form a relationship with the enterprise. Labor relations are subject to the "Labor Law" and are protected by the labor law. The prerequisite for the establishment of labor relations is that the laborer and the company sign labor contracts, but in fact, both the unit accepting the interns and the students who go to the unit for internships do not intend to sign a formal labor contract, which results in the interns and the internship units. It does not constitute a labor relationship, and it is difficult to use labor law to restrict and manage their internship behavior (Wang, 2013).

\subsection{Lack of Legislation at the National Level, and the Legal Status of Interns Has Not Been Recognized}

At this stage, China has not formulated a legal system specifically for college interns and a comprehensive intern management system. China's current laws and regulations have not yet clarified the legal status of interns. At present, within the legal framework of our country, there is no special regulation of college student internships. Laws and regulations, but local regulations and rules are not universal. Among them, regulations related to internships are mainly reflected in: In 2002, the Ministry of Education promulgated the "Measures for Handling Student Injury Accidents", in which Article 9 clarified the safety guarantee responsibilities of colleges and universities to interns. In 2003, the General Office of the Ministry of Education issued the "Notice on Further Strengthening the Management of Internships in Secondary Vocational Schools" (Teacher Cheng Hall [2003] No. 2), which stated that secondary vocational schools should reasonably select internship units and sign an internship agreement, clarifying both parties The rights and obligations during the student internship and the management responsibilities of both parties (Mao, 2020). At present, my country has not yet started the legislative work to protect the labor rights and interests of college interns. Because college interns lack a clear "worker" status, they have 
not signed a formal labor contract with the intern unit, and fail to establish a labor relationship, so they are not covered by the "Labor Law" and "Labor Contract Law.”

\section{The Way to Construct the Labor Rights and Interests Protection Mechanism of Interns}

\subsection{Clarify the Identity of the Prospective Laborer of the Interns and the Content of Their Rights}

College interns have the dual identities of students and laborers. On the one hand, the school retains all the files and household registration relationships of interns, and manages and arranges interns. In the internship unit, the interns will also transform their professional knowledge into practice in order to better complete their studies; another on the one hand, the internship unit hires interns, the interns have paid their own labor, and the internship units also receive the results of the interns' labor, forming a de facto labor relationship, and they are quasi-laborers. The interns group is a huge group. The protection of their labor rights involves the interests of tens of millions of interns, and it has become a social issue that more and more people pay attention to. The legal ambiguity of university student status has become an important factor that plagues universities, interns and internship units, and has seriously affected the active role of internship activities. Therefore, in order to balance the interests of all parties, make up for the deficiencies of the "Labor Law", and at the same time be in line with the relevant provisions of the "Labor Contract Law", it is recommended that the relevant legislative departments of our country issue special laws, regulations or amendments on the protection of internships for college students. Define the status of college interns as "quasi-workers", and clarify the content of the rights that interns should enjoy (Wu, 2019).

\subsection{Regulate the Signing of the "Internship Guarantee Agreement"}

The education administration department should issue red-head documents for the internship issues of college students, compulsory universities, internship units and interns to sign an internship agreement before the student internship, and clearly incorporate the rights, obligations and responsibilities of all parties into the internship agreement. It is also beneficial for interns to provide timely and effective relief in accordance with the content of the agreement after an accident occurs during the internship. The internship agreement regulates the interns' working hours, salary standards, labor safety, liability for damages, insurance obligations, etc., so as to protect the labor rights of interns. Relevant government departments should strengthen supervision, strengthen the standardized management of college student internships, and strictly control the interns. Before entering the market, interns must sign a tripartite agreement with the internship unit and colleges and universities. In this way, internships are in- 
stitutionalized and standardized, and the legitimate rights and interests of interns are effectively protected.

\subsection{Implementation of Liability Insurance}

Interns are more likely to have unexpected risks during the internship process than during the school period. In order to prevent them from happening, a specific social insurance mechanism should be established as a guarantee for college students' internships. It is recommended that the state implement internship liability insurance nationwide specifically for internship guarantees for college students, and establish an insurance system with compulsory social insurance as the mainstay and commercial insurance as a supplement to prevent the liability risks of college interns internships as much as possible and eliminate them at the same time. It relieves the worries of schools, enterprises and students, avoids social conflicts caused by improper handling of accidental injuries during the internship, and is conducive to building a civilized and harmonious society (Zhang \& Yang, 2019). Internship liability insurance is mandatory for all colleges and universities that offer internship courses, companies that accept interns, and students participating in internships. In the event of a work-related accident, the intern will be paid by the intern's work-related injury insurance fund, and the school and the intern unit are not required to bear the responsibility. The insurance fee can be paid by the school, the student and the internship unit in proportion.

\subsection{Implement a Strict Internship Management System}

In our country, the identity of interns is still students, under the management of the school. Internships are an extension of teaching activities, and schools should also be responsible for interns. In order to meet the requirements of the market for talents, the school should strengthen communication and exchanges with the internship unit on the way of talent training. Schools should implement a strict internship management system: tracking students' internships, optimizing the content of the internship assessment system, objectively evaluating the quality of internship projects of internship units, and inspecting the results of student internships in a timely manner. Add legal policy consultation and psychological counseling to the guidance of the Employment Guidance Center, establish an internship rights protection center, and arrange professional teachers to provide assistance to students in rights protection. The school formulates and perfects an internship manual to guide students to choose a suitable formal internship unit. Publicize the labor rights of interns and how to maintain them by conducting practical lectures on internships and publishing internship information on the school's official public account. Companies take the initiative to cooperate with universities, provide high-quality internship positions, carry out systematic and comprehensive training, explore the potential of interns, and reserve more outstanding talents for the future development of the company (Wang, 2013). 


\section{Summary}

Through the investigation and research of this article, according to the current status of the labor rights protection of college interns in Chengdu, problems are found, and the root causes of the problems are analyzed in depth, and a way to construct a labor rights protection mechanism for interns is proposed. This research allows people to learn more about the current status of the labor rights protection of college interns, understand their fundamental problems, start from the root causes, and take measures to effectively protect the labor rights of college interns, improve the quality of internships, and avoid internships. The conflicts caused by the infringement of the labor rights and interests of the students are conducive to solving the problem of difficult internships for college students.

\section{Conflicts of Interest}

The authors declare no conflicts of interest regarding the publication of this paper.

\section{References}

Du, M. F. (2015). Investigation on the Status Quo of Labor Rights and Interests of Interns in Colleges and Universities. Legal Expo, No. 20, 35-37.

Feng, P. (2015). On the Perfection of the Protection Mechanism of the Rights and Interests of Interns in My Country. Legal System and Society, No. 16, 47+54.

Mao, R. N. (2020). On the Labor Rights Protection System of Interns. Fujian Quality Management, No. 12, 197.

Wang, L. L. (2013). The Legal Gap of "Interns" Needs to Be Filled Urgently. China Human Resources and Social Security, No. 3, 40-41.

Wu, J. N. (2019). On the Legal Protection of the Labor Rights and Interests of University Interns. Legal Expo, No. 25, 73-74.

Zhang, Y. F., \& Yang, W. H. (2019). On the Protection of the Labor Rights of Interns in Higher Vocational Colleges. Modern Vocational Education, No. 5, 70-71. 